\title{
IN VITRO DEGRADATION OF LINAMARIN BY MICROORGANISMS ISOLATED FROM CASSAVA WASTEWATER TREATMENT LAGOONS
}

\author{
Vasconcellos, S. P' ${ }^{1}$; Cereda, M. P. ${ }^{2}$; Cagnon, J. R. ${ }^{3}$; Foglio, M.A. ${ }^{1}$; Rodrigues, R.A. ${ }^{1}$; Manfio, G. P. ${ }^{3}$; Oliveira, V. M. ${ }^{1}$ \\ ${ }^{1}$ Centro de Pesquisas Químicas, Biológicas e Agrícolas, Universidade Estadual de Campinas, Paulínia, SP, Brasil; ${ }^{2}$ Centro de \\ Tecnologias para o Agronegócio, Universidade Católica Dom Bosco, Instituto São Vicente, Campo Grande, MS, Brasil; \\ ${ }^{3}$ Natura Inovação e Tecnologia de Produtos, Cajamar, SP, Brasil.
}

Submitted: September 24, 2008; Returned to authors for corrections: March 01, 2009; Approved: July 24, 2009.

\begin{abstract}
This study aimed at isolating and characterizing of microorganisms able to use linamarin as sole carbon source. Thirty one microbial strains were isolated from manipueira, a liquid effluent of cassava processing factories. Among these strains, Bacillus licheniformis (isolate 2_2) and Rhodotorulla glutinis (isolate L1) were able to degrade $71 \%$ and $95 \%$ of added linamarin, respectively, within 7 days, showing high biodegradation activity and great potential for detoxification of cassava processing wastewaters.
\end{abstract}

Key words: Bacillus, degradation, manipueira, fertirrigation.

Cassava roots can be industrially applied for obtaining starch and flour. However, cassava industries generate some undesirable sub-products, such as solid residues and a liquid effluent named manipueira, which may represent a major disposal problem due to the high organic charge and toxic potential, resulting from the presence of cyanoglucosides (4).

Cyanoglucosides are secondary metabolites produced by several plant species (7) used in animal and human diets, such as: apple, bamboo shoot, cassava, cherry, lima bean, maize, oat, peach, papaya, sorghum and wheat (25). These compounds are dispersed throughout the plant organs, mostly in non-edible parts (12), but may become concentrated in edible roots and leaves, as in the case of cassava.

Cassava (Manihot esculenta Crantz) roots and leaves contain high concentrations of linamarin (alphahydroxyisobutyronitrile-beta- $D$-glucopyranoside) lotaustralin (methyl-linamarin). Linamarin is the most abundant cyanoglucoside present in cassava cells (6) and may generate the equivalent to $0.2-100 \mathrm{mg}$ of $\mathrm{HCN}$ per $100 \mathrm{~g}$ of fresh cassava following cellular lysis (3).

Microorganisms can grow on substrates containing cyanides by anaerobic metabolism, or by using an aerobic respiration chain as an alternative pathway (5). In both pathways, $\mathrm{HCN}$ is eliminated from the substrate, and converted into a non-toxic product (11). This enzymatic cyanide-removing property can be exploited for the detoxification of cyanide-rich cassava wastewater and industrial residues. These residues currently cause serious environmental problems in many cassava flour producing plants in Brazil, the largest producer worldwide, and in many African, Latin American and Asian countries (28), where cassava products are an important input for human diet. 
Manipueira is rich in potassium, nitrogen, magnesium, phosphorous, calcium, sulfur and iron, presenting a great potential as an agronomic fertilizer. It contains cyanoglucosides, which explains the application as nematicide and insecticide (23). This study aimed at isolating and characterizing linamarin-degrading microorganisms from cassava discharges, as an initial step for their future application in agriculture.

In this context, cassava wastewater and soil samples were collected from effluent decantation lagoons at two Brazilian cassava flour and starch factories: Farinheira Plaza (Santa Maria da Serra, SP) and Fecularia Halotech Fadel (Cândido Mota, SP). Samples were collected using sterile plastic containers and kept in ice during transportation to the laboratory facilities. Wastewater from ponds $(1 \mathrm{~mL})$ and soil $(1 \mathrm{~g})$ were separately dispersed into $9 \mathrm{~mL}$ of sterile distilled water, and serial dilutions were plated onto the surface of Yeast Malt Extract Agar (Difco) supplemented with chloranfenicol $(10 \mu \mathrm{g} / \mathrm{mL})$, for the isolation of yeasts, and Nutrient Agar (Difco) supplemented with nistatin and cyclohexamide ( $50 \mu \mathrm{g} / \mathrm{mL}$ each), for the isolation of bacteria. The inoculated media were incubated at $28^{\circ} \mathrm{C}$ for up to 14 days. Also, dried soil samples were enriched by treatment by saturation with fresh cassava wastewater (collected during the production process) every 3 days. Treated samples were incubated at $28^{\circ} \mathrm{C}$ for 14 days, prior to serial dilution and plating, as described before. Isolated colonies were streaked onto fresh media containing $2 \%$ fresh cassava wastewater, added prior to autoclaving. Pure cultures, evaluated by colony morphology (macroscopic inspection) and microscopic analyses (Gram staining and phase contrast microscopy), were stored in slants at $4^{\circ} \mathrm{C}(21)$.

A total of 118 microbial isolates were recovered from the plates inoculated with soil and wastewater samples. Based on colony morphology and microscopic features, 31 different isolates (26 bacteria and 5 yeasts) were selected and subjected to linamarin degradation assays.

Selected microbial isolates $\left(1.5 \times 10^{8} \mathrm{MPN} / \mathrm{mL}\right)$ were then inoculated into $100 \mathrm{~mL}$ Erlenmeyer flasks containing 30
$\mathrm{mL}$ of liquid minimum mineral medium $\left(3 \mathrm{~g}\left(\mathrm{NH}_{4}\right)_{2} \mathrm{SO}_{4} ; 2 \mathrm{~g}\right.$ $\mathrm{KH}_{2} \mathrm{PO}_{4} ; 2$ g K $\mathrm{HPO}_{4} ; 0.5 \mathrm{~g} ; \mathrm{MgSO}_{4} .7 \mathrm{H}_{2} \mathrm{O}$, in $1 \mathrm{~L}$ distilled water) (12); added of $10 \mathrm{mg} / \mathrm{mL}$ linamarin (Sigma; 95\% purity), taken from a filter sterilized solution. The inoculated flasks were incubated in a rotary shaker $(200 \mathrm{rpm})$ at $28^{\circ} \mathrm{C}$ for up to 7 days, and microbial growth was monitored every 24 hours by spectrophotometrical readings at $605 \mathrm{~nm}$ (19). Linamarin degradation was monitored following the methodology described by Korpraditskul (14), using an HPLC system (Varian Pro Star) fitted with a Bio-Rad HPX42A column (300 x $7.8 \mathrm{~mm})$, and applying filtered distilled water as mobile phase $(0.6 \mathrm{~mL} / \mathrm{min})$, at $80^{\circ} \mathrm{C}$. Aliquots $(1$ $\mathrm{mL})$ of growth culture were filtered $(0.22 \mu \mathrm{m}$ membrane, Millipore), transferred to sealed glass vials and subjected to High Pressure Liquid Chromatography (HPLC) analysis using an autosampler system. Linamarin $(1 \mathrm{mg} / \mathrm{mL})$ was used as standard and the analyses were run in duplicate. From a total of 31 strains evaluated, only one yeast (L1) and one bacterial isolate (2_2) presented linamarin degradation activity. The yeast strain L1 was able to degrade $95.2 \%$ of the added linamarin $(6.72 \mathrm{mg} / \mathrm{mL})$ after 7 days under the evaluated assay conditions (Figure 1). The bacterial isolate 2_2 presented a short lag phase and a direct correlation between biomass increase and linamarin degradation (Figure $1)$.

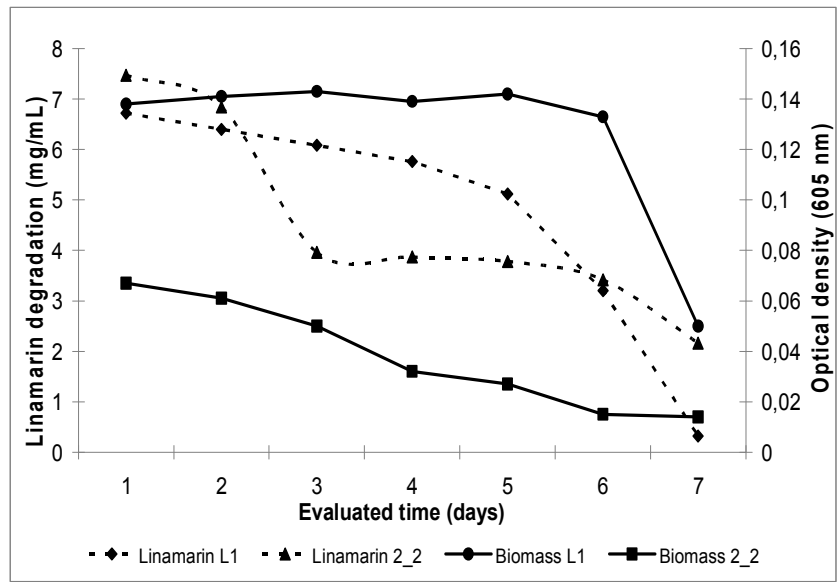

Figure 1. Biomass production and linamarin degradation presented by the yeast strain L1 and the bacterial strain 2_2. 
This strain was able to degrade linamarin from an initial concentration of $7.47 \mathrm{mg} / \mathrm{mL}$ to a final concentration of 2.16 $\mathrm{mg} / \mathrm{mL}$ (71\%), after seven days.

The degradation kinetics indicated a stable growth phase of the yeast in the medium and a high degradation activity over linamarin, close to the total mineralization (Figure 1). No previous reports of cyanoglucoside degradation by Rhodotorula sp. were found. To our knowledge, the only data of cyanoglucoside degradation by yeasts refer to strains of Candida tropicalis (20) and Candida utilis (9), but studies did not report the degradation rates.

Essers et al. (8) reported a Bacillus sp. strain isolated from Ugandan domestic fermented cassava with ability to decrease linamarin to $1 \%$ of the initial concentration. Ugwuanyi et al. (30) also described Bacillus genus bacteria, including Bacillus coagulans, Bacillus licheniformis and Bacillus stearothermophilus, able to degrade linamarin. However, in these reports, the microbial activity was detected by empirical methods such as picrate assay and $p$-nitrophenyl $\beta$-D-glucoside (PNPG) degradation. The use of HPLC for the quantification of the microbial linamarin degradation was an innovation introduced in the present work.

Taxonomic analyses were also carried out in order to identify the linamarin biodegrading cultures. The linamarindegrading yeast isolate was characterized according to Kurtzman and Fell (17), Kreger van Rij (15) and Barnett et al. (2). The identification was based on comparative analyses of morphological, physiological and biochemical data available in the literature. Taxonomic characterization indicated that the yeast strain L1 is a heterobasidiomycete without basidiospores, teleospores or baliostospores, being classified as a basidiomycete anamorph. The isolate produced carotenoid pigments and was positive for DBB and urea, and negative for inositol assimilation, production of extracellular amyloids and glucose fermentation. These features, added to strong potassium nitrate assimilation, enabled the assignment of isolate L1 to Rhodotorula glutinis (Fresenius) F. C. Harrison var. glutinis. The data presented by Kutzman and Fell (18) differed in relation to assimilation of melezitose and salicin. This species is widely distributed in nature, and has been isolated from a wide range of substrates $(13,28,32)$, nevertheless this is the first association with manipueira discards environment.

The bacterial isolate was identified by analysis of combined data from phenotypic features and 16S rRNA gene sequence analysis. Genomic DNA from pure culture was extracted according to Pitcher et al. (25). 16S rRNA gene fragments were amplified using the bacterial-specific primers set $27 \mathrm{f}$ and $1100 \mathrm{r}$ (19) in $50 \mu \mathrm{L}$ PCR reactions containing 50$100 \mathrm{ng}$ of genomic DNA, $5 \mu \mathrm{L}$ 10X PCR buffer (supplied with the enzyme), $0.2 \mathrm{mmol} \mathrm{L}^{-1} \mathrm{dNTP}$ mix, $1.5 \mathrm{mmol} \mathrm{L}^{-1}$ $\mathrm{MgCl}_{2}, 0.4 \mu \mathrm{mol} \mathrm{L} \mathrm{L}^{-1}$ each primer and $2 \mathrm{U}$ Taq DNA polymerase (Invitrogen). The PCR amplification was carried out using an initial denaturation step at $95^{\circ} \mathrm{C}$ for $2 \mathrm{~min}$, followed by 30 cycles of $1 \mathrm{~min}$ at $94^{\circ} \mathrm{C}, 1 \mathrm{~min}$ at $55^{\circ} \mathrm{C}$ and 3 $\min$ at $72^{\circ} \mathrm{C}$; and a final extension at $72^{\circ} \mathrm{C}$ for $5 \mathrm{~min}$. Sequencing was done using 16S rRNA internal primers (10f and 1100r) (19) using a Mega Bace 500 (GE Healthcare) automated sequencer, according to manufacturer's instructions. Phylogenetic identification was achieved by comparing the sequences obtained with $16 \mathrm{~S}$ rRNA sequence data from type strains available at the public databases Genbank (http://www.ncbi.nlm.nih.gov/) and RDP (Ribosomal Database Project, Wiscosin, USA, (http://rdp.cme.msu.edu). The sequences were aligned using the CLUSTAL X program (30) and analyzed using MEGA software (17). Evolutionary distances were derived from sequence-pair dissimilarities calculated as implemented in MEGA, using Kimura's DNA substitution model (14). The phylogenetic reconstruction was accomplished using the neighbor-joining (NJ) algorithm, with bootstrap values calculated from 1000 replicate runs.

Phylogenetic analysis based on $16 \mathrm{~S}$ rRNA gene molecular marker did not offer enough resolution to allow identification at the species level, and discrimination between B. licheniformis and B. sonorensis was not achieved (Figure 2). In order to conclude the identification at bacterial species level, phenotypic characterization tests were carried out as 
described previously by Palmisano et al. (23). For pigmentation evaluation, cells were grown in nutrient broth at $30^{\circ} \mathrm{C}$ for $24 \mathrm{~h}$ and then plated onto one of the following media at $30^{\circ} \mathrm{C}$ : pH 5.6 agar of Gordon et al. (10) and glycerol/ glutamate agar (1). For assays of salt tolerance, cultures were incubated in nutrient broth containing $0,3,5,7$ and $10 \%(\mathrm{w} / \mathrm{v}) \mathrm{NaCl}$. Triplicate culture tubes containing 6
$\mathrm{mL}$ medium were inoculated with a loopful of 18-20 h culture grown in nutrient broth at $30^{\circ} \mathrm{C}$. The inoculated tubes were incubated at $30{ }^{\circ} \mathrm{C}$ and monitored for growth at 2, 4, 7 and 14 days. The strains L1 and 2_2 were deposited at the Brazilian Collection of Environmental and Industrial Microorganisms (CBMAI), Brazil, under the accession numbers CBMAI 866 and CBMAI 867, respectively.

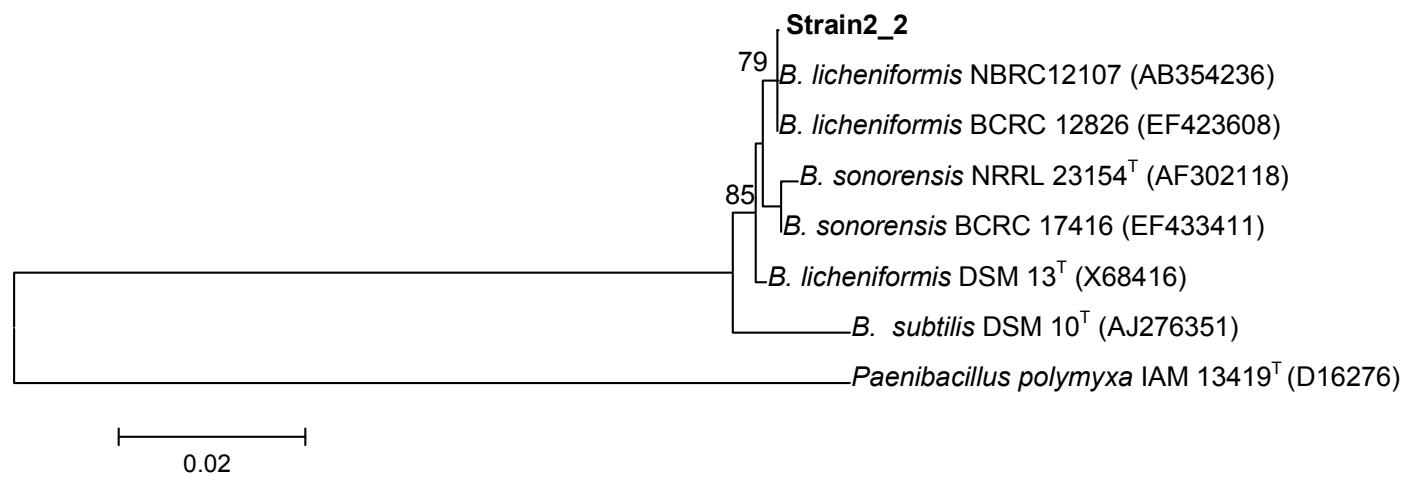

Figure 2. Phylogenetic analysis of partial 16S rRNA gene sequences of bacterial strain 2_2 and related microorganisms. Evolutionary distances were based on Kimura 2p model_and tree reconstruction on the neighbour joining method. Bootstrap values (1,000 replicate runs, shown as \%) greater than 70\% are listed. GenBank accession numbers are listed after species names. Bacillus litoralis $\mathrm{SW}-211^{\mathrm{T}}$ was used as outgroup.

The salt tolerance assays indicated that the Bacillus strain was able to grow in $0,3,5,7$ and $10 \% \mathrm{NaCl}$. When cultivated on $\mathrm{pH} 5.6$ agar, this culture was pale-cream after 4 days, maintaining the color for the 14-day monitored period. In the glycerol/glutamate medium, the culture presented a reddishbrown color after five days of monitoring. These phenotypic data allowed the identification of the bacterial strain 2_2 as Bacillus licheniformis.

The results obtained herein revealed the isolation of two microbial strains with high ability for biodegrading the cyanoglucoside linamarin. The use of such microorganisms in plants' treatment for cassava industries, which are widely distributed in Brazil, may offer a great potential for detoxification of cassava wastewaters for future application in fertirrigation.

\section{ACKNOWLEDGEMENTS}

This work was supported by research grants from FAPESP and CNPq. S. P. Vasconcellos was supported by a grant from FAPESP (98/14731-5). The authors would like to thank to CERAT (UNESP) and CPQBA (UNICAMP) for the help with the analyses. We are also indebted to Prof. Dr. Frederick M. Cohan for the culture media specifications. MAF wishes to thank $\mathrm{CNPq}$ for research fellowship. 


\section{REFERENCES}

1. Arai, T.; Mikami, Y. (1972). Chromogenicity of Streptomyces. Appl. Microbiol. 23, 402-406.

2. Barnett, J.A.; Payne, R.W.; Yarrow, D. (1990). Yeast Characteristics and Identification. Cambridge University Press, Cambridge.

3. Bradbury, J.H.; Egan, S.V.; Lynch, M.J. (1991). Analysis of cyanide in cassava using acid hydrolysis of cyanogenic glucosides. J. Sci. Food Agric. 55, 277-290.

4. Cereda, M.P. (2001). Caracterização dos subprodutos da industrialização da mandioca. In: Cereda, M.P. (ed.). Manejo, uso e tratamento de subprodutos da industrialização da mandioca. Fundação Cargill, São Paulo, p.13-37.

5. Cereda, M.P.; Brasil. O.G.; Fioretto, A.M.C. (1981). Microrganismos com respiração resistente ao cianeto isolados de líquido residual de fecularia. YTON 41, 197-201.

6. Conn, E.E. (1973). Biosynthesis of cyanogenic glycosides. Biochem. Soc. Symp. 38, 277-302.

7. Conn, E.E. (1994). Cyanogenesis - a personal perspective. Acta Hortic. 375, 31-41.

8. Essers, A.J.A.; Bennink, M.H.J.; Nout, M.J.R. (1995). Mechanisms of increased linamarin degradation during solid-substrate fermentation of cassava. W. J. Microbiol. Biotechnol. 11, 266-270.

9. Fagbemi, A.O.; Ijah, U.J.J. (2006). Microbial population and biochemical changes during production of protein-enriched fufu. $W$. $J$. Microbiol. Biotechnol. 22, 635-640.

10. Gordon, R.E.; Haynes, W.C.; Pang, C.H. (1973). Agriculture Handbook. No. 427, Department of Agriculture US, Washington, D.C.

11. Jensen, H.L.; Abdel-Ghafar, A.S. (1979). Cyanuric acid as nitrogen sources for microorganisms. Arch. Microbiol. 67, 1-5.

12. Jones, D.A. (1998). Why are so many plants cyanogenic? Phytochem. $47,155-162$.

13. Kawai, F.; Zhang, D.; Sugimoto, M. (2000). Isolation and characterization of acid- and Al-tolerant microorganisms. FEMS Microbiol. Lett. 189, 143-147.

14. Kimura, M. (1980). A simple method for estimating evolutionary rate of base substitutions through comparative studies of nucleotide sequences. J. Mol. Evol. 16, 111-120.

15. Korpraditskul, R.; Katayama, A.; Kuwatsuka, S. (1993). Chemical and microbiological degradation of atrazine in Japanese and Thai soils. $J$. Pestic. Sci. 18, 77-83.

16. Kreger-Van Rij, N.J.W. (1984). The yeast: a taxonomic study. Elsevier Science, Amsterdam.

17. Kumar, S.; Tamura, K.; Jakobsen, I.B.; Nei, M. (2001). MEGA2: molecular evolutionary genetics analysis software. Bioinformatics 17, 1244-1245.

18. Kurtzman, C.P.; Fell, J.W. (1998). The yeast: a taxonomic study. Elsevier Science, Amsterdam.
19. Lane, D.J. (1991). 16S/23S rRNA sequencing. In: Stackebrandt, E. and Goodfellow, M. (eds.) Nucleic Acid Techniques in Bacterial Systematics. John Willey \& Sons, Chinchester, p.115-175.

20. Legras, J.L.; Jory, M.; Galzy, P. (1990). Detoxification of cassava pulp using Brevibacterium sp. 312. Appl. Microbiol. Biotechnol. 33, 529533.

21. Lei, V.; Amoa-Awua, W.K.A.; Brimer, L. (1999). Degradation of cyanogenic glycosides by Lactobacillus plantarum strains from spontaneous cassava fermentation and other microorganisms. Int. J. Food Microbiol. 53, 169-184.

22. Muro, M.A.; Luchi, M.R. (1989). Preservação de microrganismos Fundação Tropical de Pesquisas e Tecnologia "André Tosello", Campinas.

23. Palmisano, M.M.; Nakamura, L.K.; Duncan, K.E.; Istock, C.A.; Cohan, F.M. (2001). Bacillus sonrensis sp. nov., a close relative of Bacillus licheniformis, isolated from soil in the Sonoran Desert, Arizona. Int. J. Syst. Evol. Microbiol. 51, 1671-1679.

24. Pantaroto, S.; Cereda, M.P. (2001). Linamarina e sua decomposição no ambiente. In: Cereda, M.P. (ed.). Manejo, Uso e Tratamento de Subprodutos da Industrialização da Mandioca. Fundação Cargill, São Paulo, p.38-47.

25. Pitcher, D.G.; Saunders, N.A.; Owen, R.J. (1989). Rapid extraction of bacterial genomic DNA with guanidine thiocyanide. Lett. Appl. Microbiol. 8, 151-156.

26. Poulton, J.E. (1983). Cyanogenic compounds in plants and their toxic effects. In: Keeler, R.F.; Tu, A.T. (eds.). Handbook of Natural Toxins. Marcel Dekker, New York, p. 117-157.

27. Roberts, R.M.; Turner, N.J.; Willetts, A.J.; Turner, M.K. (1995). Introduction to biocatalysis using enzymes and microorganisms. Cambridge University Press, Cambridge.

28. Romero, M.C.; Hammer, E.; Cazau, M.C.; Arambarri, A.M. (2002). Isolation and characterization of biarylic structure - degrading yeasts: hydroxylation potential of dibenzofuran. Environ. Poll. 118, 379-382.

29. Tatsuma, T.; Komori, K.; Yeoh, H.H.; Oyama, N. (2000). Disposable test plates with tyrosinase and $\beta$-glucosidases for cyanide and cyanogenic glycosides. Anal. Chim. Acta 408, 233-240.

30. Thompson, J.D.; Gibson, T.J.; Plewniak, F.; Jeanmougin, F.; Higgins, D.G. (1997). The ClustalX windows interface: flexible strategies for multiple sequence alignment aided by quality analysis tools. Nucleic Acids Res. 24, 4876-4882.

31. Ugwuanyi, J.O.; Harvey, L.M.; McNeil, B. (2007). Linamarase activities in Bacillus spp. Responsible for thermophilic aerobic digestion of agricultural wastes for animal nutrition. Waste Manag. 27, 1501-1508.

32. Welthagen, J.J.; Viljöen, B.C. (1999). The isolation and identification of yeasts obtained during the manufacture and ripening of cheddar cheese. Food Microbiol. 16, 63-73. 